\title{
Feasibility of iron loaded 'okara' for biosorption of phosphorous in aqueous solutions
}

\author{
T. A. H. Nguyen ${ }^{\text {a }}$, H. H. Ngo ${ }^{a^{*}}$, W. S. Guo ${ }^{\text {a }}$, J. Zhang ${ }^{\text {b }}$, S. Liang ${ }^{\text {b }}$, K. L. Tung ${ }^{c}$ \\ ${ }^{a}$ Centre for Technology in Water and Wastewater, School of Civil and Environmental Engineering, \\ University of Technology, Sydney, Broadway, NSW 2007, Australia \\ ${ }^{\mathrm{b}}$ Shandong Key Laboratory of Water Pollution Control and Resource Reuse, School of Environmental \\ Science \& Engineering, Shandong University, Jinan 250100, PR China \\ ${ }^{c}$ Department of Chemical Engineering, National Taiwan University, Taipei 106, Taiwan
}

* Corresponding author: School of Civil and Environmental Engineering, University of Technology, Sydney (UTS), P.O. Box 123, Broadway, NSW 2007, Australia. Tel.: +61 295142745 ; Fax: +61 29514 2633. E-mail address: ngohuuhao121@gmail.com

\begin{abstract}
This study investigated the feasibility of using soybean milk by-products (okara) as a sustainable biosorbent for phosphate removal in water and wastewater. The results show that raw okara could hardly decontaminate phosphate from aqueous solutions. Hence, in this work, okara was modified by being cationized using $\mathrm{FeCl}_{3} 0.25 \mathrm{M}$ (namely iron loaded okara, ILO) to enhance the phosphorus adsorption capacity. The phosphate sorption onto ILO was well achieved under the conditions of $\mathrm{pH} 3$, initial phosphorous concentration of $25 \mathrm{mg} / \mathrm{L}$, biosorbent dose of $20 \mathrm{mg} / \mathrm{L}$ and contact time of 7 hours.

Based on Langmuir model, the maximum adsorption capacity of phosphate by ILO was $4.785 \mathrm{mg} / \mathrm{g}$. The effects of interfering anions were in the order of $\mathrm{CO}_{3}{ }^{2-}>\mathrm{SO}_{4}{ }^{2-}>\mathrm{NO}_{3}{ }^{-}$. It was also observed that $\mathrm{Fe}$ (III) was detached during operation. This problem can hinder the sustainable usability of ILO. Thus, further research would be necessary for improving the modification method.
\end{abstract}

Keywords: Adsorption capacity; Cationization; Iron loaded okara; Phosphate removal 


\section{Introduction}

Phosphorous plays a critical role in the development of agriculture and industry (Benyoucef and Amrani, 2011). However, the current phosphate rock reserve could be depleted in 50-100 years (Cooper et al., 2011). Meanwhile, eutrophication can be induced by high concentrations of phosphorous $(>0.02 \mathrm{mg} / \mathrm{L})$ in receiving water bodies (Ismail, 2012). Therefore, the removal of phosphorous from water and wastewater is necessary to avoid water deterioration and diminish rely on limited phosphorous rock sources.

A variety of technologies have been employed for phosphate removal. Each of these methods has their own advantages and limitations (Table 1). However, biosorption has become a new trend in this field of study (Jyothi et al, 2012) which can effectively to purify wastewater with low contents of phosphorous (De-Bashan and Bashan, 2004; Han et al., 2005). Moreover, biosorption is believed to reduce the cost of water treatment, owing to the use of renewable, readily available and low-priced materials (Nguyen et al., 2012). Another advantage is the eco-friendly property of biosorption, which allows developing useful materials for water treatment from agricultural waste and byproducts (Li et al., 2012). Particularly, biosorption offers a potential of phosphorous recovery (Biswas et al., 2007; De-Basan and Basan, 2004). It is estimated that about 250,000 tones of phosphorous can be recovered from wastewater in Western Europe annually (Biswas et al. 2007).

\section{Table 1}

There is a growing interest in the use of renewable agricultural by-products to develop innovative, cost-effective and sustainable biosorbents for phosphorous decontamination. Earlier studies demonstrated that different agricultural by-products could be modified to effectively retain phosphorous, e.g. sawdust (Benyoucef and 
Amrani, 2011); sugarcane bagasse fibers (Carvalho et al., 2011); date-palm wastes (Ismail, 2012); coir pith (Krishnan and Haridas, 2008); eggshell (Mezenner and Bensmaili, 2009); date palm fibers (Riahi et al., 2009); wheat straw (Xu et al., 2009); etc. This can be attributed to the fact that large amounts of hydroxyl groups in the cellulose, hemicelluloses, and lignin make agricultural by-products easily and effectively involve in chemical modifications (Benyoucef and Amrani, 2011; Xu et al., 2010).

Cationization of agricultural by-products using metal salts is widely used to activate their phosphorous capture ability. Many articles have been published so far, confirming the enhanced phosphorous removal of metal loaded biosorbents (Biswas et al., 2007; Carvalho et al., 2011; Eberhardt et al., 2006; Krishnan and Haridas, 2008; Mezenner and Bensmaili, 2009). However, little information is available on the leachability of metals, which plays a decisive role to the repeated utilization of biosorbents.

Okara is a by-product of soy beverage and tofu production. It is white and quite similar to wet sawdust in its texture and form. Okara is also named as soybean residue, soy pulp, bean curd dreg, tofuzha or douzha (Chinese), tofukasu (Japanese), or bejee (Korean). It contains 50\% crude fiber, composing of cellulose, hemicellulose and lignin. Every 1,000 liters of soy milk make about $250 \mathrm{~kg}$ of okara. Thus, it is estimated that each year approximately 14 million tons of okara are generated all over the world, causing environmental burden. In addition, fresh okara degrades quickly. For that reason, though okara can be used for many purposes (e.g. animal food, fermentation substrate, fertilizer, etc.), it commonly dumped and burned as waste (Li et al., 2012). Some types of soybean by-products were used as environmentally friendly materials, such as soybean hulls (Marshall and Wartelle, 2004); lees materials (Adachi et al., 
2005) and bean dregs ( $\mathrm{Li}, 2009)$. It was found that these materials exhibited good sorption abilities to heavy metals, organochlorine compounds, and some anions. However, no previous studies have reported the use of okara for phosphate elimination.

Okara was chosen in this study because of its dominant advantages, such as easy acquiring, abundant availability enough for large-scale applications, and low price. Consequently, the application of okara as a biosorbent of phosphate may help to reduce the cost of water treatment. Also, it allows eliminating okara as a waste product in a green way. Furthermore, okara contains phosphorous inside (400-440 mg P/g dry okara), giving a platform for phosphorous recovery from both original okara and wastewater (Li et al., 2012). The main objective of this study is to develop an innovative, cost-effective and sustainable biosorbent for phosphate removal from soybean milk by-product (okara). The material was cationized using $\mathrm{FeCl}_{3} 0.25 \mathrm{M}$ to activate its phosphorous sorption capacity. The ILO before and after sorption was characterized using Fourier transform infrared spectroscopy (FTIR) analyzer. The influential factors (e.g. $\mathrm{pH}$, dose, initial concentration, contact time, foreign anions) were investigated for the process optimization. The maximum adsorption capacity of phosphorous by ILO was determined from Langmuir isotherm model. Unusual results of desorption study and Fe(III) leachability was elucidated. Based on that, useful recommendations for improving the modification method were proposed.

\section{Materials and Methods}

\subsection{Chemicals}

All chemicals in this work are of analytical grade and supplied by Chemsupply, Australia. The phosphorous stock solution containing $1000 \mathrm{mg}$ P/L was prepared by dissolving disodium hydrogen phosphate $\left(\mathrm{Na}_{2} \mathrm{HPO}_{4}\right)$ powders in distilled water, using a 
$1000 \mathrm{ml}$ volumetric flask. The phosphorous working solutions were prepared by diluting the phosphorous stock solution with distilled water to the desired concentrations.

The $\mathrm{NaOH} 0.05 \mathrm{M}$ and $\mathrm{FeCl}_{3}$ 0.25 $\mathrm{M}$ solutions were prepared by dissolving specific amounts of $\mathrm{NaOH}$ pellets and $\mathrm{FeCl}_{3} \cdot 6 \mathrm{H}_{2} \mathrm{O}$ in the distilled water.

\subsection{Preparation of ILO}

The biosorbent in this study was developed from okara. As okara is a by-product of tofu and soy milk production, it can be easily collected from soy milk factories or families at no cost or very little priced.

To prepare ILO, the raw okara was put on a sieve of $150 \mu \mathrm{m}$ and washed with distilled water before it was kept in the dry oven at $110^{\circ} \mathrm{C}$ for $24 \mathrm{~h}$. Next, $40 \mathrm{~g}$ dried okara was stirred with $1 \mathrm{~L} \mathrm{NaOH} 0.05 \mathrm{M}$ at the speed of $120 \mathrm{rpm}$, room temperature for $24 \mathrm{~h} . \mathrm{NaOH}$ pretreated okara was then washed with distilled water again until $\mathrm{pH}$ of the washing solution reached 7. After that, obtained okara was stirred with $800 \mathrm{~mL} \mathrm{FeCl}$ $0.25 \mathrm{M}$ at the speed of $120 \mathrm{rpm}$, room temperature for $24 \mathrm{~h}$. Consequently, Fe(III) pretreated okara was carefully washed with distilled water to remove all free Fe(III) cations remained on the surface of okara. Finally, it was dried in the oven at $110{ }^{\circ} \mathrm{C}$ for $24 \mathrm{~h}$ and powdered to a fine mesh of size with a Breville coffee ' $\mathrm{n}$ ' spice grinder before it can be used for adsorption experiments.

\subsection{Characterization of materials}

Fourier transform infrared (FT-IR) spectroscopy is a useful technique. It allows a qualitative and preliminary analysis of the main functional groups on the biosorbent surface, which may be responsible for the phosphate retention. FTIR spectrum of pristine and phosphorous laden okara were recorded with SHIMADZU FTIR 8400S (Japan) in mid-IR wave number range $\left(600-4000 \mathrm{~cm}^{-1}\right)$. 


\subsection{Adsorption kinetic experiments}

The adsorption kinetic experiments were conducted using a series of $50 \mathrm{~mL}$

Erlenmeyer flasks, tightly covered with aluminum foil, without any $\mathrm{pH}$ adjustment. 0.5 $\mathrm{g}$ of ILO was taken into $25 \mathrm{~mL}$ of disodium hydrogen phosphate $\left(\mathrm{Na}_{2} \mathrm{HPO}_{4}\right)$ of $100 \mathrm{mg}$ $\mathrm{P} / \mathrm{L}$. The flasks were put on an orbital shaker and shaken vigorously at $120 \mathrm{rpm}$, room temperature for $24 \mathrm{~h}$ to ensure the equilibrium was reached. After different predetermined time intervals, each flask was taken and filtered with filter paper Whatman ${ }^{\circledR}, \mathrm{GF} / \mathrm{C}$, Cat No 1822-047. All samples were kept for phosphorous analysis. The amount of adsorbed phosphorous was calculated based on the difference in the concentration between phosphorous solutions before and after adsorption.

\subsection{Desorption experiments}

To evaluate the desorption capacity of phosphorous from phosphorous bearing ILO, different elution solutions were employed, including the distilled water at various $\mathrm{pH}$ values $(2,4,6,8,10,12), \mathrm{NaOH} 0.25 \mathrm{M}$ and $\mathrm{HCl} 0.1 \mathrm{M}$.

The suspension from adsorption test was filtered with $0.45 \mu \mathrm{m}$ filter paper. Next, the phosphorous laden solids remaining on the filter papers were washed with abundant amount of tap water and then with distilled water to remove all free phosphorous anions. After that, the solids were collected into $50 \mathrm{~mL}$ erlenmeyer flasks containing $25 \mathrm{~mL}$ of different desorption solutions. Consequently, all flasks were shaken on an orbital shaker at $120 \mathrm{rpm}$, room temperature for $24 \mathrm{~h}$. When the contact time was over, all samples were filtered. The solutions were taken for determining the amount of desorbed phosphorous.

\subsection{Phosphorous analysis method}

The phosphorous concentrations were determined spectrophotometrically by molybdenum blue method on Spectroquant ${ }^{\circledR}$ NOVA 60 (Germany) machine, 
corresponding to its analysis procedure. The dilution was made where necessary to ensure the phosphorous concentrations in all samples were below $5 \mathrm{mg}$ P/L. All measurements were conducted in triplicate. The data represented the average values.

\subsection{Determination of iron}

In order to identify the side effects of employing ILO as a biosorbent for the remediation of phosphorous, the samples after adsorption and desorption processes were taken for Fe(III) analysis. The iron concentration was determined by Microwave Plasma-Atomic Emission Spectrometer (MP-AES) - Agilent Technologies 4100.

\section{Results and Discussion}

\subsection{Characterization of ILO}

Table 2 presents functional groups and the corresponding infrared adsorption bands of ILO before and after adsorption of phosphorous. Numerous adsorption peaks are listed in Table 2, implying the complicated nature of ILO. Adsorption at 3548, 3423, 3405 and $3357 \mathrm{~cm}^{-1}$ is assigned to bonded hydroxyl groups $\left(\mathrm{OH}^{-}\right)$of alcohols and phenols in modified okara (Riahi et al., 2009). The bands at 3290, 3162 and $3083 \mathrm{~cm}^{-1}$ are characteristics of $\mathrm{O}-\mathrm{H}$ group in carboxylic acids \& derivatives. The band at 2376

$\mathrm{cm}^{-1}$ is attributed to P-H of phosphine group (Ismail, 2012). The band intensity of alcohols \& phenols as well as carboxylic acids \& derivatives of ILO after adsorption has shifted compared with that before adsorption. The band shifts indicated that $\mathrm{O}-\mathrm{H}$ (alcohols \& phenols), O-H (carboxylic acids \&derivatives) and $\mathrm{P}-\mathrm{H}$ (phosphine) were major binding sites for the attachment of phosphorous onto ILO.

\section{Table 2}




\subsection{The phosphorus capture by ILO}

In this study, the Langmuir isotherm model was chosen to calculate the maximum adsorption capacity of phosphorous by ILO. The Langmuir equation and its linear form are described by the equation (1) and (2), respectively as follows (Mallampati and Valiyaveettil, 2013):

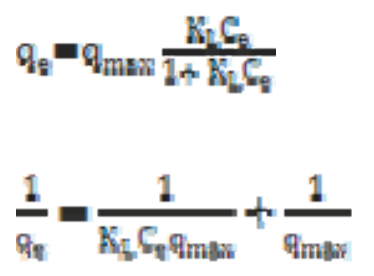

where $C_{e}$ is the equilibrium phosphorous concentration in liquid phase $(\mathrm{mg} / \mathrm{L})$, and $\mathrm{q}_{\mathrm{e}}$ is the amount of phosphorous adsorbed onto $1 \mathrm{~g}$ of the adsorbent $(\mathrm{mg} / \mathrm{g}), \mathrm{K}_{\mathrm{L}}$ is a Langmuir constant $(\mathrm{L} / \mathrm{mg})$ relevant to the energy of adsorption, and $\mathrm{q}_{\max }$ is the maximum phosphorous sorption capacity ( $\mathrm{mg} / \mathrm{g}$ ), $\mathrm{R}^{2}$ is the correlation coefficient. The linear regression method, which is based on the slope and intercept of the linear plot between $1 / \mathrm{q}_{\mathrm{e}}$ and $1 / \mathrm{C}_{\mathrm{e}}$, was used to calculate the values of $\mathrm{q}_{\mathrm{m}}, \mathrm{K}_{\mathrm{L}}$ and $\mathrm{R}^{2}$.

The Freundlich model is expressed as the equation (3) (Mallampati and Valiyaveettil, 2013), where $\mathrm{K}_{\mathrm{f}}$ and $\mathrm{n}$ are Freundlich constants associated with sorption capacity and sorption intensity of the adsorbent, respectively. The Freundlich constants were calculated, using the same method as for Langmuir, for a comparison purpose.

The results are presented in Table 3.

$$
\ln \mathrm{q}_{\mathrm{g}}=\ln K_{p}+\frac{1}{\mathrm{n}} * \ln \mathrm{\Omega}_{\mathrm{g}}
$$

\section{Table 3}

As can be seen in Table 3, Langmuir model represented a better fit than Freundlich model, indicating that the sorption of phosphorous onto ILO was probably monolayer. 
Also, the surface of ILO might be homogeneous. The Freundlich constant value $1<\mathrm{n}<$ 10 revealed that the sorption of phosphorous onto ILO was favorable (Boujelben et al., 2008). The $1 / \mathrm{n}$ value for $\mathrm{PO}_{4}{ }^{3-}(0.225)$ was below 1 , referring to the normal Langmuir isotherm (Mallampati and Valiyaveettil, 2013).

Table 3 indicates that the maximum adsorption capacity of phosphorous by ILO was $4.785 \mathrm{mg} / \mathrm{g}$. Meanwhile, the initial investigations showed that raw okara exhibited very low adsorption capacity $(0.8 \mathrm{mg} \mathrm{P} / \mathrm{g})$ and removal efficiency (4\%) for phosphate ions (initial phosphorus concentration of $100 \mathrm{mg} / \mathrm{L}$, biosorbent dose of $5 \mathrm{~g} / \mathrm{L}$, shaking speed of $200 \mathrm{rpm}$ after $24 \mathrm{~h}$ of contact time at room temperature). It means that ILO was 5.98 times more efficient than raw okara in remediating phosphorus from aqueous solutions. Apparently, impregnation of okara with $\mathrm{FeCl}_{3} 0.25 \mathrm{M}$ considerably improved its phosphorous retention. In spite of the differences in nature and chemical composition between okara and sugarcane bagasse, the results of the present study fit well with the findings reported by Carvalho et al. (2011). The authors claimed that the phosphorous remediation capacity was increased by $45 \%$ due to the incorporation of $\mathrm{Fe}(\mathrm{II})$ onto of sugarcane bagasse fiber surface. By comparing the removal between carboxymethylated material (94\%) and non-carboxymethylated material (97\%), they concluded that the presence of $\mathrm{Fe}(\mathrm{II})$ in the fibers played a decisive role in enhancing phosphorous capture, whilst the carboxymethylation enabled the attachment of Fe(II). These results are in line with those reported by Jyothi et al. (2012). Accordingly, the presence of tenfold excess of cations, e.g. $\mathrm{Ca}^{2+}, \mathrm{Mg}^{2+}, \mathrm{Cu}^{2+}, \mathrm{Zn}^{2+}, \mathrm{Fe}^{2+}$ and $\mathrm{Ni}^{2+}$ boosted the removal percentage of phosphorous.

As shown in Table 4, the maximum adsorption capacity of phosphorous by ILO is not really high compared with the literature data. This implies that Fe(III) may be inappropriate for cationization of okara. To further improve the sorption capacity of 
phosphorous, other metals should be tested to substitute for Fe(III) ions. Besides, adsorption experiments need to be conducted at the optimum conditions. Despite of the limited adsorption capacity of phosphorous, original okara is still recommended for developing biosorbents of phosphorous, with the advantage of being abundantly available, cost effective, renewable and environmentally benign material.

\section{Table 4}

\subsection{Optimization of phosphorous biosorption process}

\subsection{Effect of $p H$}

The $\mathrm{pH}$ plays an important role in the adsorption process by affecting the chemical speciation of phosphate anions and the ionization of active functional groups on sorbent surfaces. To evaluate the effect of $\mathrm{pH}$ on the sorption of phosphorous onto ILO, batch experiments were performed at a fixed initial phosphorous concentration $(100 \mathrm{mg} / \mathrm{L})$, biosorbent dose (20 g/L), shaking speed (130 rpm), room temperature, while varying $\mathrm{pH}$ values $(3,5,7,10)$. The $\mathrm{NaOH}$ and $\mathrm{HCl}$ solutions of different concentrations were used to adjust $\mathrm{pH}$ values of phosphorous solutions with a $\mathrm{pH}$ meter (HANA-HI 9126 model). It was found that, the removal percentage (\%) of phosphorous decreased from $95.74 \%$ to $90.85 \%$ with an increase of $\mathrm{pH}$ from 3 to 10 . The optimum $\mathrm{pH}$ for the removal of $\mathrm{PO}_{4}{ }^{3-}$ by ILO was 3 . The binding of $\mathrm{PO}_{4}{ }^{3-}$ anions was most efficient in acidic medium. High $\mathrm{pH}$ values suppressed the attachment of $\mathrm{PO}_{4}{ }^{3-}$ onto ILO surface. This can be explained by the fact that at high $\mathrm{pH}$ values, the surface of ILO became more negatively charged due to $\mathrm{OH}^{-}$ions, leading to a higher competition with $\mathrm{PO}_{4}{ }^{3-}$ anions. In contrast, low $\mathrm{pH}$ boosted the adsorption of $\mathrm{PO}_{4}{ }^{3-}$ anions, because of the electrostatic interactions. It is interesting that, despite of fluctuations in $\mathrm{pH}$, the minimum removal (90.85\%) was still extremely high. Thus, $\mathrm{pH}$ did not show significant effects on the phosphorus removal using ILO. 
Similar trend was observed by Ismail (2012) in case of adsorption of phosphorous onto date palm wastes. The results of the current study relative to the optimum $\mathrm{pH}$ fit well with the findings reported by Biswas et al. (2007) and Krishnan \& Haridas (2008), who claimed that $\mathrm{pH} 3$ favored the retention of $\mathrm{PO}_{4}{ }^{3-}$ anions by $\mathrm{Fe}(\mathrm{III})$ loaded orange waste gel and $\mathrm{Fe}(\mathrm{III})$ coated coir pith, respectively. However, different $\mathrm{pH}$ values were found to be effective in previous studies conducted by Benyoucef and Amrani (2011); Jyothi et al. (2012); Kumar et al. (2010); Xu et al. (2010); Yue et al. (2010). This is probably due to the difference in nature and composition of various agro-based materials used.

To explore the effect of ILO dose on the removal of phosphorous, adsorption experiments were conducted at a constant initial phosphorous concentration (100 mg $\mathrm{P} / \mathrm{L})$; temperature $\left(25^{\circ} \mathrm{C}\right), \mathrm{pH}$ (non-adjusted), and contact time $(24 \mathrm{~h})$ but with various Fe(III) loaded okara doses $(1,2,5,10,15,20 \mathrm{~g} / \mathrm{L})$. It was found that the phosphorous removal was augmented remarkably from $2 \%$ to $90.67 \%$ as the dose of ILO increased from $1 \mathrm{~g} / \mathrm{L}$ to $20 \mathrm{~g} / \mathrm{L}$. The more efficient capture of $\mathrm{PO}_{4}{ }^{3-}$ anions at a higher ILO dose resulted from a larger surface area (Kumar et al., 2010) or more available binding sites (Xu et al., 2009; Yue et al., 2010). Optimum dose was selected to be $20 \mathrm{~g} / \mathrm{L}$ as the removal of $\mathrm{PO}_{4}^{3-}$ anions kept increasing until that dose. In addition, the ILO dose of 20 $\mathrm{g} / \mathrm{L}$ resulted in exceptionally high removal efficiency $(90.67 \%)$ at the initial phosphorous concentration of $100 \mathrm{mg} / \mathrm{L}$. Furthermore, higher doses may lead to the decrease in the phosphorous removal because of particle aggregation, which is likely to reduce the total surface area of ILO (Mezenner and Bensmaili, 2009). The optimum dose in the present study (20 g/L) is higher when compared with the literature data, e.g. 2 g/L (Xu et al., 2009); 4 g/L (Kumar et al., 2010); 5 g/L (Ismail, 2012); 10 g/L (Mezenner and Bensmaili, 2009). Even so, the applicability of ILO as a biosorbent for 
the phosphorous removal should not be interfered because of its easy acquiring, abundantly available and low-priced characteristics.

\subsubsection{Effect of initial phosphorous concentration}

\section{Figure 1}

Batch experiments were conducted to examine the effect of different initial concentrations of phosphorous $(10,25,50,100,200,250,350,450,100 \mathrm{mg} / \mathrm{L})$ on the phosphorous removal by ILO at a fixed ILO dose of $10 \mathrm{~g} / \mathrm{L}$, $\mathrm{pH}$ values of 5-6, temperature of $298 \mathrm{~K}$, shaking speed of $130 \mathrm{rpm}$ and contact time of $24 \mathrm{~h}$. The results are shown in Figure 1, showing that the higher the initial phosphorous concentration, the lower was the removal percentage of phosphorous attained. The removal percentage of $\mathrm{PO}_{4}{ }^{3-}$ by ILO declined drastically from $96.03 \%$ to $20.30 \%$ with an increase in the initial concentration of phosphorous from $10 \mathrm{mg} / \mathrm{L}$ to $500 \mathrm{mg} / \mathrm{L}$. The optimum initial concentration of phosphorous was $25 \mathrm{mg} / \mathrm{L}$, as a further decrease in initial concentration did not result in a significant increase in the removal percentage of phosphorous. The removal percentage of phosphorous was lower at higher initial concentrations, owing to enhanced ratios between phosphate moles and available adsorption sites (Mezenner and Bensmaili, 2009). This can be explained by the fact that, the number of binding sites and thus the amount of phosphorous adsorbed are constant for a certain dose of ILO, whilst the quantity of phosphorous in the solution grows with increasing initial phosphorous concentrations. Likewise, the removal percentage of phosphate was found to decline from $95 \%$ to $64 \%$ with an increase in the phosphorous concentration from 2.8 $\mathrm{mg} / \mathrm{L}$ to $110 \mathrm{mg} / \mathrm{L}$ (Mezenner and Bensmaili, 2009). These results are in harmony with those reported by Kumar et al. (2010) and Xu et al. (2009). The former attributed this to an increase in driving force at higher initial phosphorous concentrations, whereas the latter suggested that the phosphorous concentration gradient facilitated the sorption. 


\subsubsection{Effect of contact time}

\section{Figure 2}

The influence of the contact time was examined by conducting experiments at a fixed phosphorous concentration (100 mg/L), biosorbent dose (20 g/L), temperature $(298 \mathrm{~K}), \mathrm{pH}$ values (5-6). The effect of contact time on the sorption of $\mathrm{PO}_{4}{ }^{3-}$ onto ILO can be observed in Figure 2, indicating that the sorption of phosphorous occurred in three stages. A very rapid removal of phosphorous took place in the first stage, reaching above 55\% within first 15 minutes. After this time, the removal kept rising but in a lower rate, achieving above $90.5 \%$ after 7 hours. Then the removal tended to be unchanged, reaching the maximum of $91.7 \%$ after $24 \mathrm{~h}$. Hence, 7 hours was chosen as the optimum contact time for sorption of phosphorous onto ILO. However, to ensure the equilibrium is attained, $24 \mathrm{~h}$ is proposed as a contact time for next experiments. The results achieved in this study are more or less in agreement with those quoted by Biswas et al. (2007). Accordingly, it was noticed that, $15 \mathrm{~h}$ was necessary to attain the equilibrium in case of removing phosphate by $\mathrm{Fe}(\mathrm{III}), \mathrm{La}(\mathrm{III}), \mathrm{Ce}(\mathrm{III})$ loaded orange wastes.

\subsubsection{Effect offoreign anions}

The real wastewater usually contains many kinds of anions that may hinder the sorption of $\mathrm{PO}_{4}{ }^{3-}$ anions. For that reason, the effect of coexisting anions on the sorption of phosphorous onto ILO was investigated to elucidate the practical applicability of ILO. A series of adsorption experiments were set up with the presence of $\mathrm{SO}_{4}{ }^{2-}, \mathrm{NO}_{3}{ }^{-}, \mathrm{CO}_{3}{ }^{2-}$ individually and collectively. The concentration of coexisting anions was 10 times higher than that of phosphate ions in mol ratios. The operating conditions were initial phosphorous concentration (100 mg/L $3 \mathrm{mmol})$, ILO dose (20 g/L), orbital shaking rate $(130 \mathrm{rpm})$, temperature ( $298 \mathrm{~K})$, and contact time ( $24 \mathrm{~h})$. The ability of the above 
foreign anions to compete with $\mathrm{PO}_{4}{ }^{3-}$ for binding sites on ILO was calculated using the Equation (4) given by Shin et al. (2005). The results are displayed in the Figure 3.

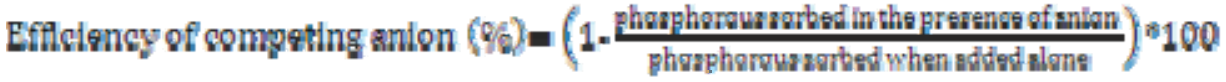

\section{Figure 3}

Figure 3 points out that the presence of $\mathrm{SO}_{4}{ }^{2-}$ and $\mathrm{NO}_{3}{ }^{-}$anions separately could hardly hamper the sorption of phosphorous onto ILO, whereas $\mathrm{CO}_{3}{ }^{2-}$ anions demonstrated the largest effect on the process, followed by a combination of 3 anions

$\left(\mathrm{SO}_{4}{ }^{2-}+\mathrm{CO}_{3}{ }^{2-}+\mathrm{NO}_{3}{ }^{-}\right)$. The removal of phosphorous using ILO was reduced by $79.29 \%$, $57.66 \%, 4.81 \%$ and $3.06 \%$ in the addition of $\mathrm{CO}_{3}{ }^{2-}$, all three anions, $\mathrm{SO}_{4}{ }^{2-}$ and $\mathrm{NO}_{3}{ }^{-}$ anions, respectively. The efficiency of competing anions was in the order $\mathrm{CO}_{3}{ }^{2-}$ $(85.96 \%)>\mathrm{SO}_{4}{ }^{2-}+\mathrm{CO}_{3}{ }^{2-}+\mathrm{NO}_{3}{ }^{-}(62.51 \%)>\mathrm{SO}_{4}{ }^{2-}(5.22 \%)>\mathrm{NO}_{3}{ }^{-}(3.32 \%)$. Based on this, it would appear that ILO should not be applied for remediating phosphorous from wastewater with high levels of $\mathrm{CO}_{3}{ }^{2-}$ anions. These findings agree with earlier studies performed by Biswas et al. (2007, 2008); Jyothi et al. (2012), associated with the effect of $\mathrm{SO}_{4}{ }^{2-}$ and $\mathrm{NO}_{3}{ }^{-}$anions. On the other hand, the finding of the present study relative to the effect of $\mathrm{CO}_{3}{ }^{2-}$ anions was just converse to the observations of above authors, who claimed that the interference effects of $\mathrm{CO}_{3}{ }^{2-}$ were marginal.

\subsection{Desorption of phosphorous from phosphorous bearing ILO}

The recovery of phosphate anions and the reusability of ILO play critical roles to the actual application of this biosorbent. The desorption efficiencies of phosphorous from phosphorous bearing ILO with diverse eluents are depicted in Figure 4. It can be inferred that the distilled water at $\mathrm{pH}$ values of 2, 4, 6, 8, 10 exhibited very poor desorption capacities $(<20 \%)$. In contrast, the distilled water at $\mathrm{pH} 12, \mathrm{NaOH} 0.25 \mathrm{M}$ and $\mathrm{HCl} 0.1 \mathrm{M}$ were found to be excellent elution solutions with extremely high 
desorption efficiencies (>94\%). It is worth mentioning that the desorption percentage in cases of using $\mathrm{NaOH} 0.25 \mathrm{M}$ and $\mathrm{HCl} 0.1 \mathrm{M}$ as elution solutions were even higher than $100 \%$. The unusual desorption results can be explained by the assumption that raw okara may contain some phosphorous, which was eluted together with phosphorous adsorbed onto ILO. This hypothesis was strongly supported by the experimental data, which displayed that significant amounts of phosphorous can be eluted into aqueous solutions from dry okara by $\mathrm{H}_{2} \mathrm{SO}_{4}, \mathrm{HCl}$, and $\mathrm{NaOH} 0.05 \mathrm{M}$. These findings more or less agree with a preceding study conducted by Li et al. (2012), revealing that the phosphorous content in original okara was 396-444 mg/ $100 \mathrm{~g}$ dry matter. These results imply that, the extraction of phosphorous from native okara via the pretreatment with $\mathrm{NaOH} 0.05 \mathrm{M}$ was incomplete. This also highlights the potential of enhancing the efficiency of phosphorous recovery via conducting it with both original okara at the beginning and with phosphorous bearing ILO at the end of the process. For that reason, there is room for improvement of procedures for phosphorous removal and recovery by metal loaded okara.

\section{Figure 4}

\subsection{Iron released during sorption and desorption tests}

The detachment of Fe(III) from ILO during its sorption performance is undesirable, owing to the possible losses in its sorption capacity in next sorption cycles together with the deterioration of the effluent water quality. To investigate the leachability of Fe(III) from ILO during adsorption and desorption tests, batch experiments were undertaken under specific operating conditions as follows: initial phosphorous concentration of 100 $\mathrm{mg} / \mathrm{L}$, ILO dose of $10 \mathrm{~g} / \mathrm{L}$, orbital shaking rate of $130 \mathrm{rpm}$, temperature of $298 \mathrm{~K}$, contact time of $24 \mathrm{~h}$. Different elution solutions were employed, including the distilled water at different $\mathrm{pH}$ values $(2,4,6,8,10,12), \mathrm{NaOH} 0.25 \mathrm{M}$, and $\mathrm{HCl} 0.1 \mathrm{M}$. 
Figure 4 reveals that free Fe(III) ions could be found in the aqueous solutions at the end of desorption tests. The elution of Fe(III) ions was trivial with such eluents as distilled water at $\mathrm{pH}$ values of 4, 6, 8, and 10. Conversely, the significant amounts of $\mathrm{Fe}$ (III) were detected when the distilled water at $\mathrm{pH}$ values of $2,12, \mathrm{NaOH} 0.25 \mathrm{M}$ and $\mathrm{HCl} 0.1 \mathrm{M}$ were used. It would seem that, the extreme $\mathrm{pH}$ values of desorption solutions resulted in higher detachment of Fe(III) from ILO. Due to a significant leachability of Fe(III) during operation, Fe(III) may not be appropriate for cationization of okara. Hence, it needs replacing by alternative metals.

Equally, it was found that, the detachment of Fe(III) ions from ILO was significant in the adsorption test. The concentration of $\mathrm{Fe}(\mathrm{III})$ ions fluctuated in the range from $12.285 \mathrm{mg} / \mathrm{L}$ to $17.916 \mathrm{mg} / \mathrm{L}$. The further investigations showed that the release of $\mathrm{Fe}(\mathrm{III})$ decreased from $32.56 \mathrm{mg} / \mathrm{L}$ to $15.13 \mathrm{mg} / \mathrm{L}$ with an increase in the initial phosphorous concentrations from $2 \mathrm{mg} / \mathrm{L}$ to $100 \mathrm{mg} / \mathrm{L}$ (Figure 5). The release of Fe(III) was lower at higher initial concentrations of phosphorous. This can be explained by the fact that more $\mathrm{Fe}(\mathrm{III})$ ions inyolved in complexation with $\mathrm{PO}_{4}{ }^{3-}$, leading to a reduction in the number of free $\mathrm{Fe}(\mathrm{III})$ ions eluted into aqueous solutions.

\section{Figure 5}

Similar observation was noticed by Biswas et al. (2007) in case of removal of phosphorous with La(III) loaded orange waste gel. They explored that La(III) was released into aqueous solutions when $\mathrm{HCl} 0.4 \mathrm{M}$ was employed as a desorption solution. Unfortunately, the detail data could not be detected. These results are in harmony with those reported earlier by Shin et al. (2005), who discovered that the leachability of $\mathrm{La}$ (III) from $\mathrm{La}(\mathrm{III})$ loaded bark fiber was above $85 \%$ at $\mathrm{pH}$ of 2.5 . 


\subsection{The prospect of using metal loaded biosorbents for phosphorous elimination}

In general, biosorbents do not show significant affinity towards $\mathrm{PO}_{4}{ }^{3-}$ in water bodies, owing to the lack of available binding sites, which are responsible for sorption of anions (Eberhardt and Min, 2008; Marshall and Wartelle, 2004). Consequently, to enhance their sorption capacity of phosphorous, biosorbents need to be cationized via impregnating with metal compounds or grafting with ammonium type chemicals (Han et al., 2005; Mallampati and Valiyaveettil, 2013; Nguyen et al., 2012; Orlando et al., 2002). Due to its simplicity and effectiveness, the former is usually method of choice. The common metals used for this purpose include Fe(II, III), Zr(IV), La(III), Ce(III), and $\mathrm{Zn}(\mathrm{II})$. The biosorbents which are directly immersed into metal solutions usually exhibit insufficient capacity for phosphate sequestering (Eberhardt et al., 2006). Thus, base treatments or grafting of carboxylate groups are necessary for improving the attachment of metals onto the material surface (Biswas et al., 2008; Carvalho et al., 2011; Eberhardt et al., 2006). Many articles have been published so far, confirming the enhanced phosphorous removal of metal loaded biosorbents (Biswas et al., 2007;

Carvalho et al., 2011; Eberhardt et al., 2006; Krishnan and Haridas, 2008; Mezenner and Bensmaili, 2009). It is worth mentioning a study performed by Krishnan and Haridas (2008), reporting that the phosphorous uptake by coir pith expanded up to 6 times, as a result of impregnating with $\mathrm{FeCl}_{3}$. However, little information is available on the leachability of metals during operation, which may significantly influence the repeated utilization of metal loaded biosorbents. Table 5 reveals that $\mathrm{Zr}(\mathrm{IV})$ is superior to other metals used for cationization of biosorbents, because of its low leachability. However, the relatively high cost and toxicity of $\mathrm{Zr}(\mathrm{IV})$ compounds may hinder its widespread applications. Therefore, further improvements are required in this direction of research. The appropriate metals for this purpose should meet such requirements as 
high phosphate removal efficiency, minor elution during operation, low price, and low toxicity to the public and environmental health. From that point of view, this study may be considered as a starting point for further research on enhancement of phosphate removal from water and wastewater using metal loaded okara.

\section{Table 5}

\section{Conclusions}

ILO demonstrated a relatively high phosphorous sorption capacity $(4.785 \mathrm{mg} / \mathrm{g})$. The $\mathrm{CO}_{3}{ }^{2-}$ anions interfered the phosphorous biosorption the most, whilst competing effects of $\mathrm{SO}_{4}{ }^{2-}$ and $\mathrm{NO}_{3}{ }^{-}$anions were negligible. Despite extremely high phosphorous removal efficiency (> 90\% at initial phosphorus concentration of $100 \mathrm{mg} / \mathrm{L}$, biosorbent dose of $20 \mathrm{~g} / \mathrm{L}$ ), the demerit of ILO was found from the strong detachment of Fe(III) during operation. As a final remark, alternative metals for cationization should be examined in the future study.

\section{Acknowledgments}

The authors gratefully thank the Australian Development Scholarships in Vietnam (ADSiV) for granting the AusAID scholarship. We would like to acknowledge the Centre for Technology in Water and Wastewater (CTWW), School of Civil and Environmental Engineering, University of Technology, Sydney (UTS) for the technical support. The research collaboration between UTS and Shandong University is also highly appreciated.

\section{References}

1. Adachi, A., Hamamoto, H., Oknano, T., 2005. Use of lees materials as an adsorbent for removal of organochlorine compounds or benzen from wastewater. Chemosphere, 58, 817-822.

2. Biswas, B.K., Inoue, K., Ghimire, K.N., Ohta, S., Harada, H., Ohto, K., Kawakita, H., 2007. The adsorption of phosphate from aquatic environment using metal-loaded orange waste. J. Colloid Interface Sci. 312, 214-223.

3. Biswas, B.K., Inoue, K., Ghimire, K.N., Harada, H., Ohto, K., Kawakita, H., 2008. Removal and recovery of phosphorus from water by means of adsorption onto orange waste gel loaded with zirconium. Bioresour. Technol. 99, 8685-8690. 
4. Benyoucef, S., Amrani, M., 2011. Removal of phosphorus from aqueous solutions using chemically modified sawdust of Aleppo pine (Pinus halepensis Miller): Kinetics and isotherm studies. Environmentalist 31, 200-207.

5. Boujelben, N., Bouzid, J., Elouear, Z., Feki, M., Jamoussi, F., Montiel, A., 2008. Phosphorous removal from aqueous solution using iron coated natural and engineered sorbents. J. Hazard. Mater. 151, 103-110.

6. Carvalho, W.S., Martins, D.F., Gomes, F.R., Leite, I.R., Gustavo da Silva, L., Ruggiero, R., Richter, E.M., 2011. Phosphate adsorption on chemically modified sugarcane bagasse fibers. Biomass Bioenergy 35, 3913-3919.

7. Cooper, J., Lombardi, R., Boardman, D., Marquet, C.C., 2011. The future distribution and production of global phosphate rock reserves. Resour. Conserv. Recycl. 57, 78-86.

8. De-Basan, L.E., Basan, Y., 2004. Recent advances in removing phosphorous from wastewater and its future use as fertilizer (1997-2003). Water Res. 38, $4222-4246$

9. Eberhardt, T.L., Min, S.H., Han, J.S., 2006. Phosphate removal by refined aspen wood fiber treated with carboxymethyl cellulose and ferrous chloride. Bioresour. Technol., 97, 2371-2376.

10. Eberhardt, T.L., Min, S.H., 2008. Biosorbents prepared from wood particles treated with anionic polymer and iron salt: effect of particle size on phosphate adsorption. Bioresour. Technol., 99, 626-630.

11. Han, J.S., Min, S. H., Kim, Y.K., 2005. Removal of phosphorous using AMD treated lignocellulosic material. Forest Prod. J. 55, 48-53.

12. Ismail, Z., 2012. Kinetic study for phosphate removal from water by recycled date-palm wastes as agricultural byproducts. Int. J. Environ. Stud. 69, 135-149.

13. Jyothi, M.D., Rohini Kiran, K., Ravindhranath, K., 2012. Phosphate pollution control in waste water using new bio-sorbents. Int. J. Water Resour. Environ. Eng. 4, 73-85.

14. Karthikeyan, K.G., Tshabalala, M.A., Wang, D., Kalbasi, M., 2004. Solution chemistry effects on orthophosphate adsorption by cationized solid wood residues. Environ. Sci. Technol. 38, 904-911.

15. Krishnan, K.A., Haridas, A., 2008. Removal of phosphate from aqueous solutions and sewage using natural and surface modified coir pith. J. Hazard. Mater. 152, 527-535.

16. Kumar, P., Sudha, S., Chand, S., Srivastava, V.C., 2010. Phosphate removal from aqueous solution using coir-pith activated carbon. Sep. Sci. Technol. 45, 1463-1470.

17. Li, B., Qiao, M., Lu, F., 2012. Composition, nutrition, and utilization of okara (soybean residue). Food Rev. Int. 28, 231-252.

18. Li, L., 2009. Adsorption of Cd(II) and Zn(II) from aqueous solutions by raw bean dregs. Master thesis, College of environmental science and engineering, human university, China, Globalthesis.com.

19. Marshall, W.E., Wartelle, L.H., 2004. An anion exchange resin from soybean hulls. J. Chem. Technol. Biotechnol. 79, 1286-1292.

20. Mallampati, R., Valiyaveettil, S., 2013. Apple peels - a versatile biomass for water purification? ACS Appl. Mater. Interfaces, 5, 4443-4449. 
21. Mezenner, N.Y., Bensmaili, A., 2009. Kinetics and thermodynamic study of phosphate adsorption on iron hydroxide-eggshell waste. Chem. Eng. J. 147, 87-96.

22. Namasivayam, C., Sangeetha, D., 2004. Equilibrium and kinetic studies of adsorption of phosphate onto $\mathrm{ZnCl}_{2}$ activated coir pith carbon. J. Colloid Interface Sci. 280, 359-365.

23. Ngo, H.H., Guo, W.S., 2009. Membrane fouling control and enhanced phosphorous removal in an aerated submerged membrane bioreactor using modified green bioflocculant. Bioresour. Technol. 100, 4289-4291.

24. Nguyen, T.A.H., Ngo, H.H., Guo, W.S., Nguyen, T.V., 2012. Phosphorous removal from aqueous solutions by agricultural byproducts: A critical review. J. Water Sustainability 2, 193-207.

25. Orlando, U.S., Baes, A.U., Nishijima, W., Okada, M., 2002. A new procedure to produce lignocellulosic anion exchangers from agricultural waste materials. Bioresour. Technol. 83, 195-198.

26. Park, H.J., Na, C.K., 2006. Preparation of anion exchanger by amination of acrylic acid grafted polypropylene nonwoven fiber and its ion exchange property. J. Colloid Interface Sci., 301, 46-54.

27. Riahi, K., Thayer, B.B., Mammou, A.B., Ammar, A.B., Jaafoura, M.H., 2009. Biosorption characteristics of phosphates from aqueous solution onto Phoenix dactylifera L. date palm fibers. J. Hazard. Mater. 170, 511-519.

28. Shindo, T., Takao, Y., Ikeuchi, T., Ozawa, S., 2010. Adsorption of phosphorous from aqueous solutions onto zirconium loaded activated carbons derived from lignocellulosic residues. Int. J. Soc. Mater. Eng. Resour. 18, 24-31.

29. Shin, E.W., Karthikeyan, K.G., Tshabalala, M.A., 2005. Orthophosphate sorption onto lanthanum treated lignocellulosic sorbents. Environ. Sci. Technol. 39, 6273-6279.

30. Tshabalala, M.A., Karthikeyan, K.G., Wang, D., 2004. Cationized milled pine bark as an adsorbent for orthophosphate anions. J. Appl. Polym. Sci. 93, $1577-1583$.

31. Wu, D., Zhang, B., Li, C., Zhang, Z., Kong, H., 2006. Simultaneous removal of ammonium and phosphate by zeolite synthesized from fly ash as influenced by salt treatment. Colloid Int. Sci., 304, 300-306.

32. Xu, X., Gao, B., Wang, W., Yue, Q., Wang, Y., Ni, S., 2009. Adsorption of phosphate from aqueous solutions onto modified wheat residue: Characteristics, kinetic and column studies. Colloids Surfaces B: Biointerfaces 70, 46-52.

33. Xu, X., Gao, B., Yue, Q., Zhong, Q., 2010. Preparation of agricultural byproduct based anion exchanger and its utilization for nitrate and phosphate removal. Bioresour. Technol. 101, 8558-8564.

34. Zeng, L., Li, X., Liu, J., 2004. Adsorptive removal of phosphate from aqueous solutions using iron oxide tailings. Water Res. 38, 1318-1326.

35. Yue, Q., Wang, W., Gao, B., Xu, X., Zhang, J., Li, Q., 2010. Phosphate removal from aqueous solution by adsorption on modified giant reed. Water Environ. Res. 82, 374-381. 


\section{FIGURE CAPTIONS}

\section{Figure 1}

Effect of initial phosphorous concentration on the biosorption of $\mathrm{PO}_{4}{ }^{3-}$ anions onto ILO $\left(\mathrm{T}=298 \mathrm{~K}, \mathrm{t}=24 \mathrm{~h}\right.$, shaking speed $=130 \mathrm{rpm}, \mathrm{C}_{0}=10 \div 500 \mathrm{mg} / \mathrm{L}$, dose $=10 \mathrm{~g} / \mathrm{L} ; \mathrm{pH}$ $=5-6)$.

\section{Figure 2}

Effect of contact time on the removal of $\mathrm{PO}_{4}{ }^{3-}$ anions using ILO as a biosorbent $(\mathrm{T}=298$ $\mathrm{K}, \mathrm{t}=24 \mathrm{~h}$, shaking speed $=130 \mathrm{rpm}, \mathrm{C}_{0}=100 \mathrm{mg} / \mathrm{L}$, dose $\left.=20 \mathrm{~g} / \mathrm{L} ; \mathrm{pH}=5-6\right)$.

\section{Figure 3}

Phosphorous removal percentage of ILO in the presence of competing anions and the efficiency of competing anions

\section{Figure 4}

Desorption of phosphorous from phosphorous bearing ILO using different eluents and $\mathrm{Fe}(\mathrm{III})$ detachment during desorption tests.

\section{Figure 5}

The release of $\mathrm{Fe}(\mathrm{III})$ from ILO during adsorption tests. 


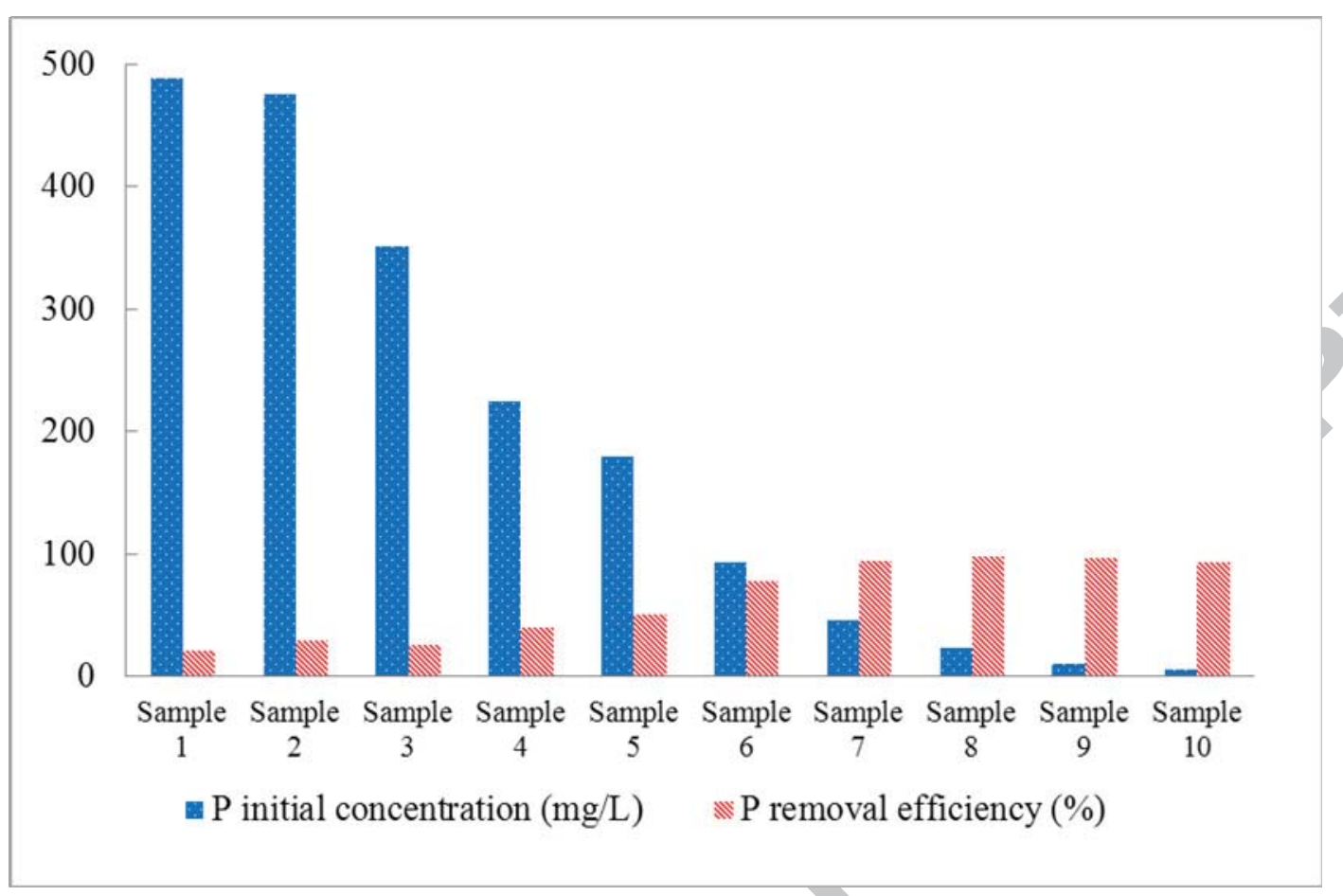

Figure 1 


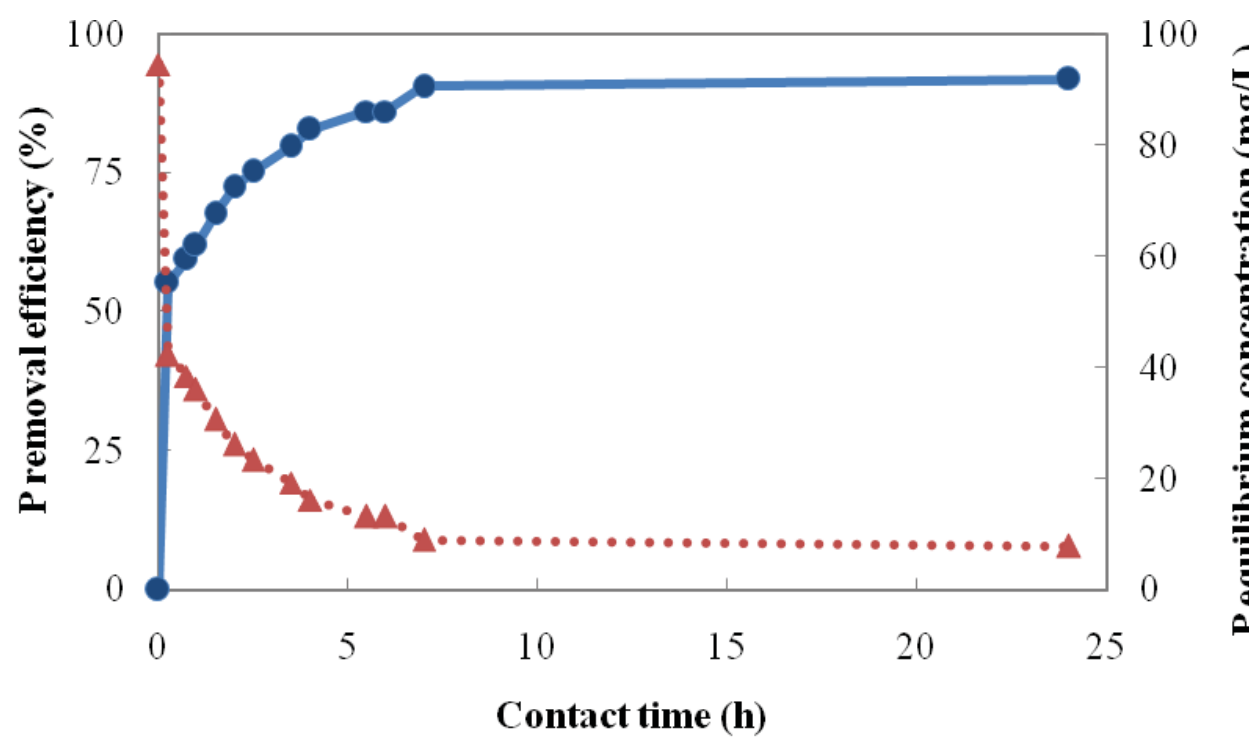

$\longrightarrow$ Removal efficiency $(\%) \quad \cdots . . \cdot$ Equilibrium $\mathrm{P}$ concentration $(\mathrm{mg} / \mathrm{L})$

\section{Figure 2}




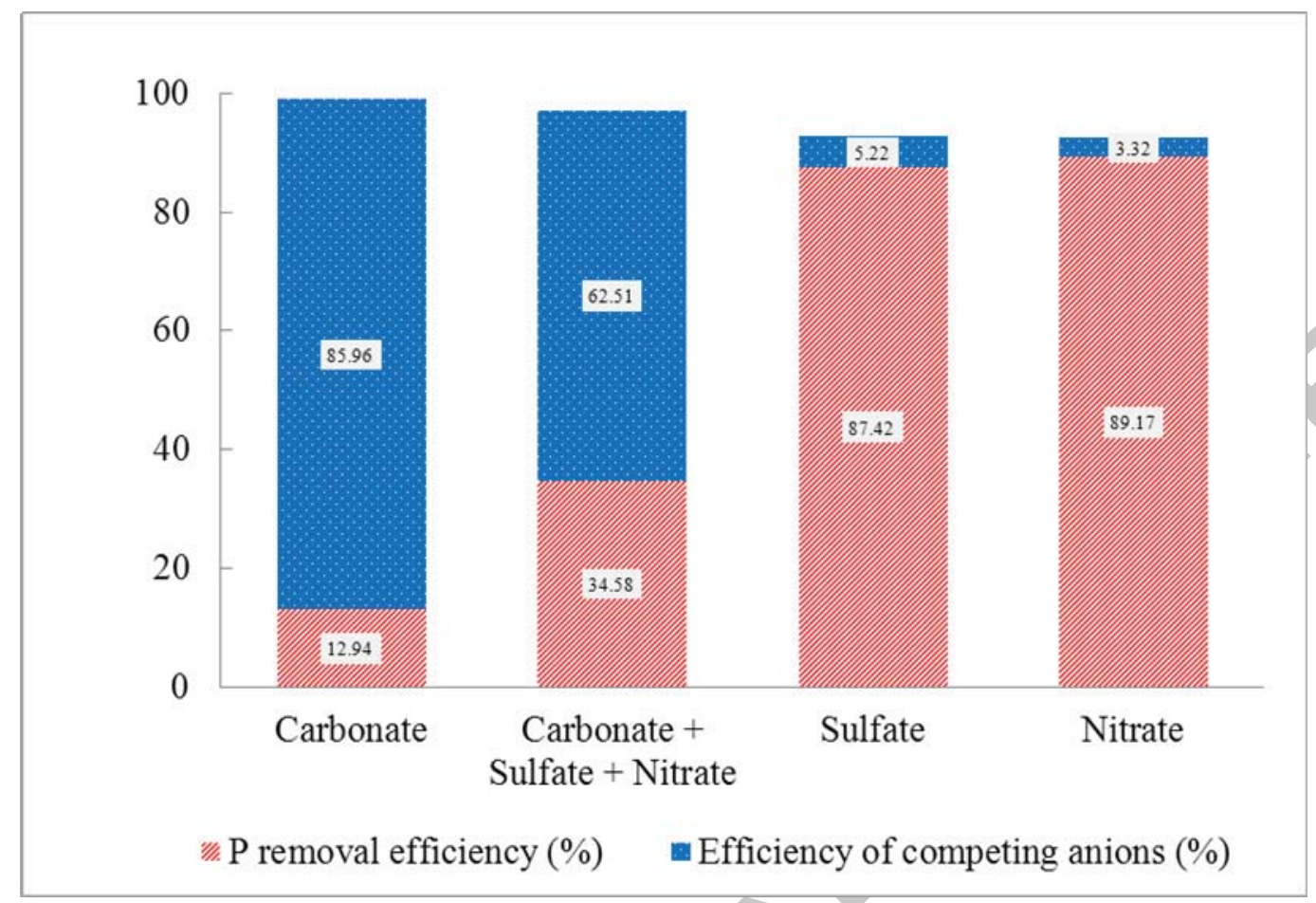

Figure 3 


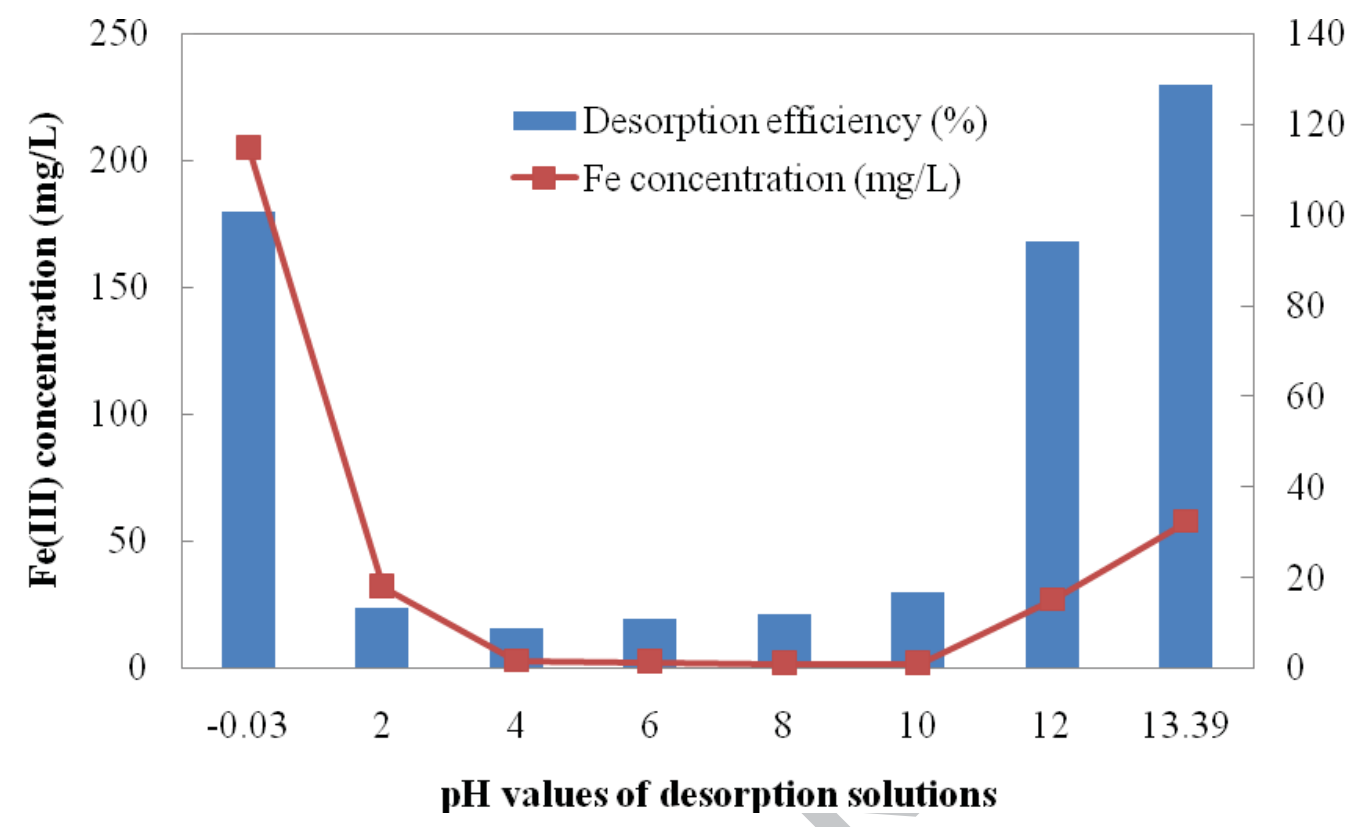

อิ

Figure 4 


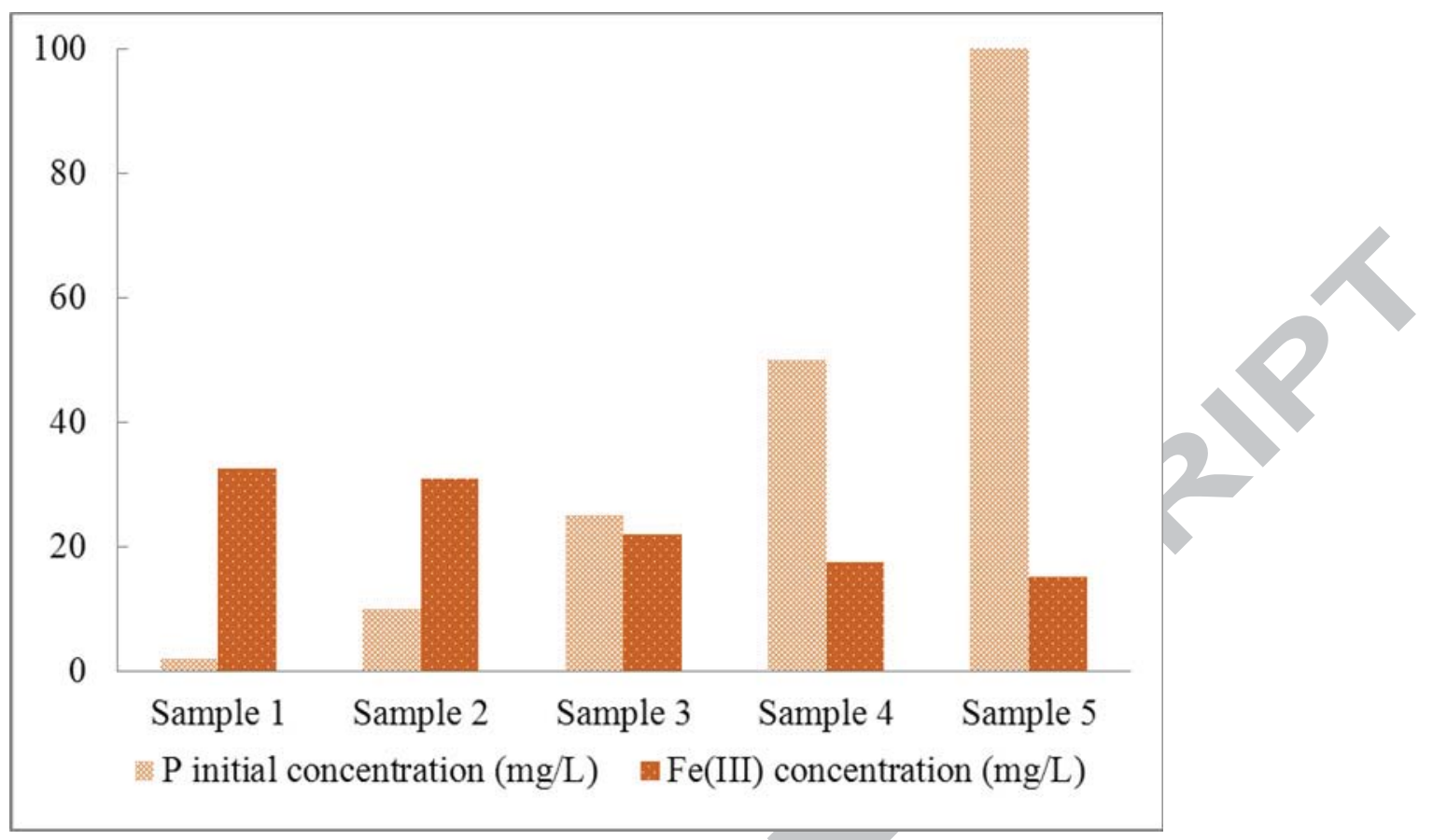

Figure 5 


\section{TABLES}

Table 1 Comparison of different technologies for phosphorous removal. ${ }^{\mathrm{a}}$

\begin{tabular}{|c|c|c|}
\hline Technology & Advantages & Disadvantages \\
\hline Chemical precipitation & $\begin{array}{l}\text { Most commonly used method } \\
\text { Easy to install, can be applied at any } \\
\text { stage during wastewater treatment } \\
\text { High P removal }\end{array}$ & $\begin{array}{l}\text { Chemicals required } \\
\text { Sludge production }\end{array}$ \\
\hline Biological P removal & $\begin{array}{l}\text { Widely used method } \\
\text { Avoiding chemical use }\end{array}$ & $\begin{array}{l}\text { External carbon source may be } \\
\text { required } \\
\text { Sensitive to changes in } \mathrm{P} \text { load and } \\
\text { temperature } \\
\text { More complex technology } \\
\text { Difficult sludge handling } \\
\text { Inefficient P recovery }\end{array}$ \\
\hline Crystallization & $\begin{array}{l}\text { Produce more marketable } \\
\text { end-product }\end{array}$ & $\begin{array}{l}\text { Chemicals and operation skills } \\
\text { necessary }\end{array}$ \\
\hline Ion exchange & $\begin{array}{l}\text { High P removal } \\
\text { Struvite produced can be reused in } \\
\text { agriculture }\end{array}$ & $\begin{array}{l}\text { High cost } \\
\text { Chemicals required } \\
\text { Complex technology } \\
\text { Low selectivity with the presence } \\
\text { of co-anions } \\
\text { Materials originated from } \\
\text { nonrenewable resources }\end{array}$ \\
\hline Magnetic & High P removal & $\begin{array}{l}\text { Chemicals required } \\
\text { Technology is complex }\end{array}$ \\
\hline Adsorption & $\begin{array}{l}\text { Appropriate for low } \mathrm{P} \text { levels } \\
\text { Potential P recovery } \\
\text { Multiple regeneration of sorbents } \\
\text { Few chemicals involved } \\
\text { Without additional sludge }\end{array}$ & $\begin{array}{l}\text { Experimental technology } \\
\text { Disposal problems after use }\end{array}$ \\
\hline Biosorption & $\begin{array}{l}\text { Cost-effectiveness } \\
\text { Originated from abundantly } \\
\text { available, low cost, environmentally } \\
\text { friendly, renewable materials }\end{array}$ & Experimental technology \\
\hline Tertiary filtration & Technology is simple & $\begin{array}{l}\text { High capital cost } \\
\text { Useless recovery product }\end{array}$ \\
\hline
\end{tabular}

${ }^{a}$ Adapted fromBiswas et al. (2007); Ismail (2012); Karthikeyan et al. (2004); Ngo and Guo (2009); Riahi et al. (2009); Tshabalala et al. (2004). 
Table 2 Functional groups analysis of ILO before and after phosphorous adsorption by FTIR.

\begin{tabular}{|c|c|c|c|c|}
\hline \multirow[t]{2}{*}{ IR peak } & \multicolumn{3}{|c|}{ Adsorption bands $\left(\mathrm{cm}^{-1}\right)$} & \multirow{2}{*}{ Assignment } \\
\hline & Before biosorption & After biosorption & Differences & \\
\hline 1 & 3546 & 3548 & +02 & $\begin{array}{l}\text { Alcohols \& Phenols: } \\
\text { O-H (H-bonded), } \\
\text { usually broad (strong) }\end{array}$ \\
\hline 2 & 3421 & 3423 & +02 & $\begin{array}{l}\text { Alcohols \& Phenols: } \\
\text { Bonded hydroxyl } \\
\text { groups }\left(\mathrm{OH}^{-}\right)\end{array}$ \\
\hline 3 & 3386 & 3405 & +19 & $\begin{array}{l}\text { Alcohols \& Phenols: } \\
\text { Bonded hydroxyl } \\
\text { groups }\left(\mathrm{OH}^{-}\right)\end{array}$ \\
\hline 4 & 3356 & 3357 & +01 & $\begin{array}{l}\text { Alcohols \& Phenols: } \\
\text { Bonded hydroxyl } \\
\text { groups }\left(\mathrm{OH}^{-}\right)\end{array}$ \\
\hline 5 & 3289 & 3290 & & $\begin{array}{l}\text { Carboxylic acids \& } \\
\text { Derivatives: O-H (very } \\
\text { broad) (strong) }\end{array}$ \\
\hline 6 & 3163 & 3162 & & $\begin{array}{l}\text { Carboxylic acids \& } \\
\text { Derivatives: O-H (very } \\
\text { broad) (strong) }\end{array}$ \\
\hline 7 & 3080 & 3083 & +03 & $\begin{array}{l}\text { Carboxylic acids \& } \\
\text { Derivatives: O-H (very } \\
\text { broad) (strong) }\end{array}$ \\
\hline 8 & 2374 & 2 & +02 & $\begin{array}{c}\text { Phosphorous } \\
\text { functions: P-H } \\
\text { phosphine (medium) }\end{array}$ \\
\hline
\end{tabular}


Table 3 Isotherms used for describing the sorption of $\mathrm{PO}_{4}{ }^{3-}$ anions onto ILO.

\begin{tabular}{cccccc}
\hline \multicolumn{3}{c}{ Freundlich } & \multicolumn{3}{c}{ Langmuir } \\
\hline $\mathrm{K}_{\mathrm{F}}(\mathrm{mg} / \mathrm{g})(\mathrm{L} / \mathrm{g})^{\mathrm{n}}$ & $\mathrm{n}$ & $\mathrm{R}^{2}$ & $\mathrm{~K}_{\mathrm{L}}(\mathrm{L} / \mathrm{mg})$ & $\mathrm{q}_{\mathrm{m}}$ & $\mathrm{R}^{2}$ \\
1.516 & 4.44 & 0.924 & 0.568 & 4.785 & 0.981 \\
\hline
\end{tabular}


Table 4 Comparison of ILO with diverse adsorbents, based on the phosphorous adsorption capacity.

\begin{tabular}{|c|c|c|}
\hline Adsorbents & $\begin{array}{c}\text { Phosphorous } \\
\text { adsorption capacity } \\
(\mathrm{mg} \mathrm{P} / \mathrm{g}) \\
\end{array}$ & References \\
\hline \multicolumn{3}{|l|}{ CONVENTIONAL ADSORBENTS } \\
\hline Zirconium ferrite & 13.00 & Biswas et al., 2008 \\
\hline Goethite & 6.42 & Han et al.,2005 \\
\hline Commercial anion exchange resins & $13.80-42.10$ & Park and Na, 2006 \\
\hline Natural zeolite & 2.15 & Wu et al., 2006 \\
\hline Iron oxide tailings & 8.21 & Zeng et al.,2004 \\
\hline \multicolumn{3}{|l|}{ UNMODIFIED BIOSORBENTS } \\
\hline Sawdust & 47.61 & Benyoucef and Amrani, 2011 \\
\hline Granular date stones & 8.70 & Ismail, 2012 \\
\hline Palm surface fibres & 8.50 & Ismail, 2012 \\
\hline Coir pith & 4.35 & Krishnan andHaridas, 2008 \\
\hline Date palm fibres & 4.35 & Riahi et al., 2009 \\
\hline Raw okara & 0.8 & THIS STUDY \\
\hline \multicolumn{3}{|l|}{ MODIFIED BIOSORBENTS } \\
\hline Sawdust of Aleppo pine (modified with urea) & 116.25 & Benyoucef and Amrani, 2011 \\
\hline Orange waste(loaded with $\mathrm{La}(\mathrm{III}), \mathrm{Ce}(\mathrm{III})$, & 13.94 & Biswas et al., 2007 \\
\hline $\mathrm{Fe}(\mathrm{III}))$ & & \\
\hline Orange waste gel (loaded with $\mathrm{Zr}$ (IV)) & 57.00 & Biswas et al., 2008 \\
\hline $\begin{array}{l}\text { Sugarcane bagasse fibres } \\
\text { (carboxymethylation }+\mathrm{FeCl}_{2} \text { ) }\end{array}$ & 152.00 & Carvalho et al., 2011 \\
\hline $\begin{array}{l}\text { Aspen wood fiber(treated with } \\
\text { carboxymethyl cellulose }+\mathrm{FeCl}_{2} \cdot 4 \mathrm{H}_{2} \mathrm{O} \text { ) }\end{array}$ & 4.30 & Eberhardt et al., 2006 \\
\hline $\begin{array}{l}\text { Juniper fiber(treated with acid mine } \\
\text { drainage) }\end{array}$ & 2.31 & Han et al., 2005 \\
\hline Coir pith(impregnated with $\mathrm{Fe}\left(\mathrm{NO}_{3}\right)_{3} \cdot 9 \mathrm{H}_{2} \mathrm{O}$ ) & 70.92 & Krishnan and Haridas, 2008 \\
\hline Eggshell(treated with iron hydroxide) & 14.49 & Mezenner and Bensmaili, 2009 \\
\hline $\begin{array}{l}\text { Wheat straw (grafted with aminated } \\
\text { intermediate) }\end{array}$ & 45.70 & Xu et al., 2010 \\
\hline Giant reed & 19.89 & Yue et al., 2010 \\
\hline Fe(III) loaded okara & 4.785 & THIS STUDY \\
\hline
\end{tabular}


Table 5 A summary of studies using metal loaded biosorbents for the decontamination of phosphorous.

\begin{tabular}{|c|c|c|c|c|}
\hline Biosorbent & Modification method & $\begin{array}{c}\text { Phosphorous } \\
\text { adsorption } \\
\text { capacity (mg/g) }\end{array}$ & Side effects & References \\
\hline $\begin{array}{l}\mathrm{La}(\mathrm{III})-, \\
\mathrm{Ce}(\mathrm{III})-, \\
\text { Fe(III)- loaded } \\
\text { orange waste } \\
\text { gel }\end{array}$ & $\begin{array}{l}\mathrm{Ca}(\mathrm{OH})_{2}+ \\
\mathrm{La}(\mathrm{III}) \text { or } \mathrm{Ce}(\mathrm{III}) \text { or } \\
\mathrm{Fe}(\text { III) solutions }\end{array}$ & $\begin{array}{c}13.94 \\
\text { (for } 3 \text { types of } \\
\text { gels) }\end{array}$ & $\begin{array}{l}\text { La(III) was } \\
\text { eluted during } \\
\text { operation }\end{array}$ & Biswas et al., 2007 \\
\hline $\begin{array}{l}\mathrm{Zr}(\mathrm{IV}) \text { loaded } \\
\text { orange waste } \\
\text { gel }\end{array}$ & $\begin{array}{l}\mathrm{Ca}(\mathrm{OH})_{2}+ \\
\mathrm{NaOH}+ \\
\mathrm{Zr}(\mathrm{IV}) \text { solution }\end{array}$ & 57.00 & $\begin{array}{l}\text { Negligible } \\
\text { detachment of } \\
\text { loaded } \mathrm{Zr}(\mathrm{IV})\end{array}$ & t al., 2008 \\
\hline $\begin{array}{l}\text { Fe(II) loaded } \\
\text { sugarcane } \\
\text { bagasse }\end{array}$ & $\begin{array}{l}\text { Carboxylmethylation } \\
+\mathrm{FeCl}_{2}\end{array}$ & 152.50 & N/A & Carvalho et al., 2011 \\
\hline $\begin{array}{l}\text { Fe(II) loaded } \\
\text { aspen wood } \\
\text { fiber }\end{array}$ & $\begin{array}{l}\text { Carboxymethyl } \\
\text { cellulose }+\mathrm{FeCl}_{2}\end{array}$ & 4.30 & $\begin{array}{l}\text { Fe(III) } \\
\text { wasleaked } \\
\text { during sorption } \\
\text { test }\end{array}$ & Eberhardt et al., 2006 \\
\hline $\begin{array}{l}\text { Fe loaded } \\
\text { juniper fiber }\end{array}$ & $\begin{array}{l}\text { Acid mine drainage } \\
(\mathrm{Fe}, \mathrm{Al}, \mathrm{Pb}, \mathrm{Zn})\end{array}$ & 2.31 & $\begin{array}{l}\text { Fe released } \\
\text { during reaction }\end{array}$ & Han et al., 2005 \\
\hline $\begin{array}{l}\text { Fe(III) loaded } \\
\text { coir pith }\end{array}$ & $\mathrm{Fe}\left(\mathrm{NO}_{3}\right)_{3}$ & 70.92 & N/A & Krishnan and Haridas, 2008 \\
\hline $\begin{array}{l}\mathrm{Zr}(\mathrm{IV}) \text { loaded } \\
\text { apple peels }\end{array}$ & $\mathrm{ZrOCl}_{2} .8 \mathrm{H}_{2} \mathrm{O}$ & 20.35 & $\mathrm{~N} / \mathrm{A}$ & Mallampatiand Valiyaveettil, 2013 \\
\hline $\begin{array}{l}\text { Iron hydroxide } \\
\text { eggshell }\end{array}$ & $\mathrm{FeCl}_{3}$ & 14.49 & "N/A & Mezenner and Bensmaili, 2009 \\
\hline $\begin{array}{l}\mathrm{Zn}(\mathrm{II}) \text { activated } \\
\text { coir pith carbon }\end{array}$ & $\mathrm{ZnCl}_{2}$ & 5.10 & N/A & Namasivayamand Sangeetha, 2004 \\
\hline $\begin{array}{l}\mathrm{Zr}(\mathrm{IV}) \text { loaded } \\
\text { activated } \\
\text { carbons from } \\
\text { rice } \\
\text { straws }\end{array}$ & $\mathrm{ZrO}\left(\mathrm{NO}_{3}\right)_{2} \cdot \mathrm{xH}_{2} \mathrm{O}$ & 11.10 & N/A & Shindo et al., 2011 \\
\hline
\end{tabular}

Note: N/A Information is not available. 


\section{Highlights}

- Iron loaded okara was evaluated as a biosorbent for phosphate removal.

- Effects of process factors on phosphate capture were fully investigated.

- P can be effectively desorbed from native okara and P laden modified okara.

- The release of Fe(III) from modified okara during operation was significant.

- Alternative metals were proposed to replace Fe(III) in cationization of okara. 